\title{
Lattice Structure Design Parameters Optimization for the Structural Integrity of Passive Vibration Isolator
}

\author{
Muhamad Syafwan Azmi (0000-0001-8238-8448)1, Rainah Ismail (0000-0002-3398-5139) 1,2, Mohd Fadzli Bin \\ Abdollah (0000-0002-2460-2888) ${ }^{1,2}$ \\ ${ }^{1}$ Fakulti Kejuruteraan Mekanikal, Universiti Teknikal Malaysia Melaka, Hang Tuah Jaya, 76100 Durian Tunggal, \\ Melaka, Malaysia. \\ ${ }^{2}$ Centre for Advanced Research on Energy, Universiti Teknikal Malaysia Melaka, Hang Tuah Jaya, 76100 Durian \\ Tunggal, Melaka, Malaysia. E-mail: P041820006@student.utem.edu.my, Rainah@utem.edu.my, Mohdfad- \\ zli@utem.edu.my
}

\begin{abstract}
Passive vibration isolator with lower natural frequency has always been a challenge due to structural integrity issues. This study presents the use of RSM statistical tool to analyze and optimize the mechanical responses of BCC lattice structure for structural integrity in a passive vibration isolator application. The optimization was done to obtain low stiffness for low natural frequency but high yield stress for optimum load-bearing capability with unit cell size and strut diameter design parameters tweak. From the results, the significance and contribution of each design parameter on each mechanical response through compression test can be understood. Results indicated changes in strut diameter produced linear growth while changes in the unit cell size produced inverse exponential responses. From optimization, a combination of $3.9 \mathrm{~mm}$ strut diameter with $10 \mathrm{~mm}$ unit cell size produced the optimum result. Therefore, it was demonstrated that RSM can provide statistical importance and contribution between input factors and their influence on each mechanical response with minimal test and cost.
\end{abstract}

Keywords: Lattice structure; Design parameter; Optimization; Structural integrity; Vibration isolator

\section{Introduction}

Lattice structure possesses intrinsically advantageous properties such as good energy absorbance capability, lightweight, and low material consumption manifesting to high specific strength (Zhang et al., 2018). Lattice structure initiated from the approximation approach from foam structure and therefore inherits the benefit of aforementioned advantages without the drawbacks such as non-uniform performance throughout the structure due to foam's manufacturing technique (Ashby et al., 2000; Hasan, 2013). This is because lattice structure is a periodic structure that stems from the repetition of a single unit cell (Helou and Kara, 2018; Rashed et al., 2016). Lattice structure can also be tailored to have closed-cell or open-cell configuration pertinent to a specific application such as crushable infill of solid structure or heat exchanger (Ngo et al., 2018). The combination of lattice structure with additive manufacturing (AM) heightens the customizability of lattice structure to a greater extent as compared to conventional manufacturing techniques such as subtractive manufacturing and formative manufacturing which won't allow for high design complexity due to manufacturing limitations. Besides that, using conventional manufacturing also led to waste which is amiss for sustainability.

Nowadays, studies have been conducted by many researchers on lattice structure encompassing a wide range of customizability, the variation in lattice structure designs is based on design parameters of a unit cell. For example, a study on compressive behavior by Abdulhadi and Mian, (2019) explored the behavior of modified body-centered cubic (BCC) lattice structure with varied strut angle and constant strut length design parameters, they found that BCC lattice with 100 degrees angle provides the highest young modulus. A study by Iyibilgin et al., (2013) investigated modified BCC lattice with variation in unit cell designs and found that the modified BCC lattice with vertical members has the highest stiffness and yield stress and in comparison, the unmodified BCC lattice produces the least stiffness and yield stress. Gautam and Idapalapati, (2019) studied the effect of layers of kagome lattice structure as well as a comparison of the uniform and functionally graded lattice and found that stiffness decreased with the increase of layers while functionally graded kagome lattice produced 35\% higher energy absorption respectively. A similar study has also been conducted by Maskery et al., (2017) where functionally graded BCC lattice exhibited 114\% higher energy absorption as compared to non-graded equals. Besides, they also studied two variants of BCC lattices; the regular and reinforced. Mahshid et al., (2016) analyzed the compressive strength of different designs of cellular structures; solid, hollow, lattice-filled, and rotated 
lattice-filled structures. They found that using latticefilled designs significantly reduced the strength as compared to the solid structure and shown no apparent changes when compared to the hollow structure.

Elmadih et al., (2017), Syam et al., (2018) and Monkova et al., (2021) explored the potential of lattice structure in passive vibration control isolator application. It should be noted that an isolator with a low natural frequency is more favorable for a wider effective isolation region. Because passive isolator is a purely mechanical system, to achieve this, compromises on the stiffness of the resilient material have to be made as a trade-off, this, unfortunately, impairs the structural integrity of the resilient material to bear a mass load. Nonetheless, the isolator must first be able to withstand a certain amount of load. For this reason, they first conducted studies on the mechanical performance of lattice structure. Syam et al., (2018) analyzed the effect of lattice design with different struts arrangements with a fixed number of nodes. Similar to Iyibilgin et al., (2013) and Maskery et al., (2017), their results revealed that models with vertical struts produced significantly higher stiffness. Meanwhile, Elmadih et al., (2017) explored the effect of unit cell size with different pre-defined volume fractions and number of layers. Changes in these design parameters can significantly affect the results of natural frequency in dynamic analysis. Monkova et al., (2021) studied the influence of unit cell size and volume ratio which is controlled by strut diameter. Their investigation discovered that increase in unit cell size produced lower young modulus and yield stress while an increase in volume ratio resulted in increased young modulus and yield stress.

Despite many studies on the variation of design parameters of the lattice structure, literature has shown that these studies were done based on the one factor at a time (OFAT) experimental approach which analyses the output response based on a single factor. This approach lacks the ability to correlate the importance and contribution of each factor, besides being unable to detect if there are significant interactions between input factors hence more time and tests are required to reach the same conclusion (Khuri and Cornell, 2018). Through the response surface methodology (RSM) design of experiment (DoE) design tool, the significance, contribution, and existence of interaction between each factor can be analyzed statistically. Moreover, this design tool can determine the optimal combination of factors for a specific application based on predefined criteria (Khuri, 2001).

There is plenty of available literature that used RSM to optimize process parameters in additive manufacturing but not the design parameters. For example, Wang et al., (2020) used RSM to investigate the effects of some laser powder bed fusion (LPBF) process parameters on the microstructure and mechanical properties of manufactured samples. They came to the conclusion that it was possible to improve mechanical properties by optimizing process parameters using RSM. Furthermore, Deng et al., (2020) used RSM to optimize the process parameters to produce 316L stainless steel samples with high density and low roughness. Terner et al., (2019) produced cobalt chrome molybdenum (Co-CrMo) samples by optimizing the laser power and scanning speed process parameters by using RSM that increase the hardness of the material. Vilanova et al., (2020) optimized the laser power, scan speed, hatch distance and scan strategy to obtain lower porosity and crack density in the Inconel 738LC (IN738LC) samples. Except for study by ElSayed et al., (2020) that used RSM to optimize design parameters namely strut diameter, strut length and strut orientation angle of diamond topological design titanium (Ti6Al4V) lattice structures for biomedical implants, to the best of the authors' knowledge, not many studies used RSM to optimize design parameters of the lattice structure.

With the focus to fill this gap, this study attempts to use RSM statistical approach to analyze and optimize the mechanical responses of the BCC lattice structure made by fused deposition modeling (FDM) AM technique. The optimization was carried out to obtain low stiffness for low natural frequency but high yield stress for the optimum load-bearing capability of passive vibration isolator using the RSM DoE design tool. The considered design parameters were the unit cell size and strut diameter. At the end of this study, the significance, contribution, and interactions of input factors can be analyzed statistically.

\section{Methodology}

\subsection{Sample preparation}

Since the advent of AM technology, the design complexity of lattice structure can be extended to many more design parameters and at the same time reduce waste as oppose to conventional manufacturing and formative manufacturing method which is good for sustainability. Nowadays, access to AM technology has become rather easier at a fairly low cost such as the fused deposition modeling (FDM) AM technique. Lattice structure samples in this study were made by utilizing the FDM AM technology (CubePro machine) into cubic lattice samples with a dimension of $60 \mathrm{~mm} 3$ from acrylonitrile butadiene styrene (ABS) thermoplastic material. The samples were modeled with a combination of design parameters in SolidWorks computer-aided design (CAD) software and saved into. STL file and later uploaded into CubePro software for slicing process. All samples were made with a similar printing process parameters combination to rule out its influence on the mechanical responses (Buonamici et al., 2018; Pernica et al., 2021). The 
combination was $200 \mu \mathrm{m}$ layer resolution, solid print strength and diamonds print pattern (Rosli et al.,
2017). Fig. 1. shows the illustration of a $60 \mathrm{~mm} 3$ tessellated BCC lattice structure and a $20 \mathrm{~mm}$ BCC oneunit cell unit cell (UC) with $5 \mathrm{~mm}$ strut diameter (SD).

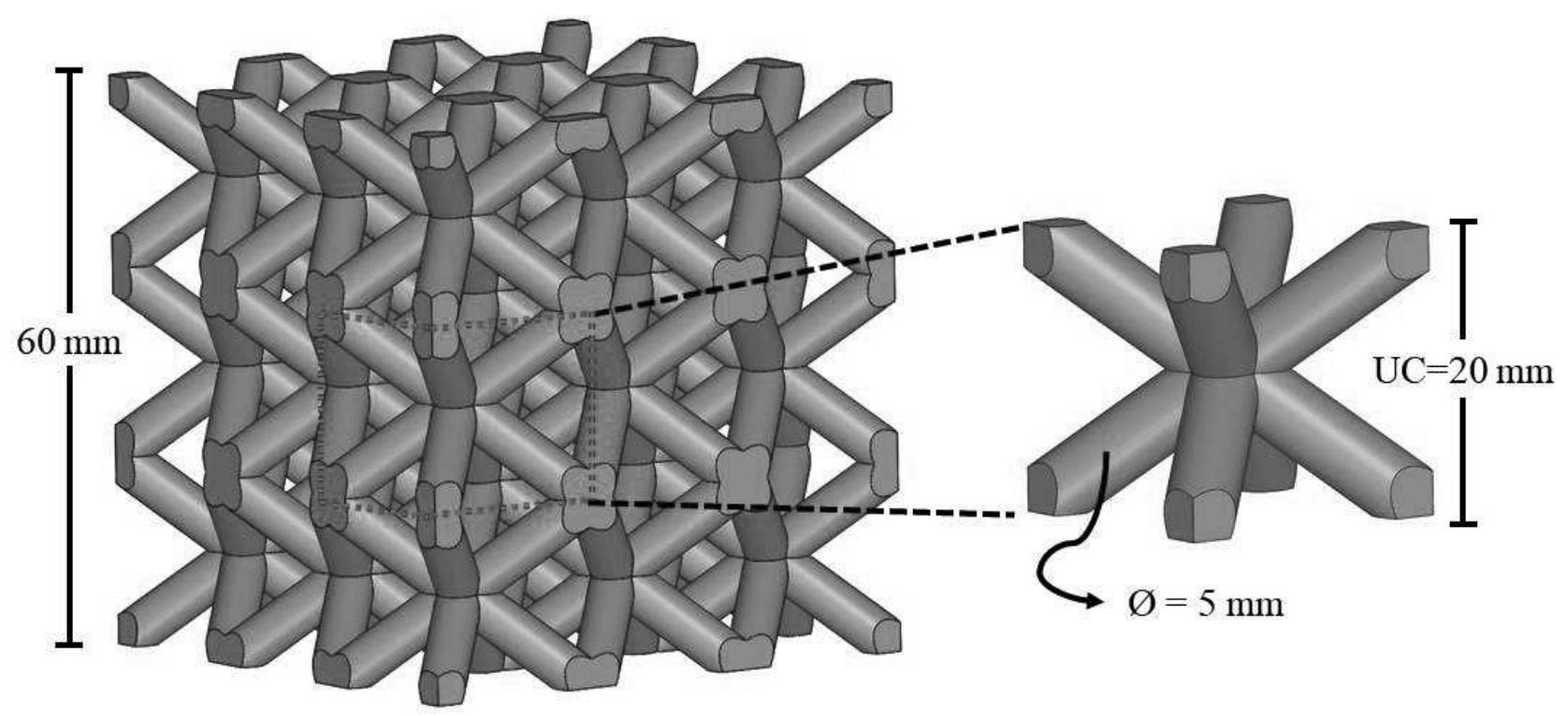

Fig. 1 Lattice structure with $20 \mathrm{~mm}$ unit cell size and $5 \mathrm{~mm}$ strut diameter

\subsection{Response surface methodology (RSM)}

RSM is a powerful statistical tool in the DoE that has been extensively used due to its prevailing capabilities in interpreting the interactions between pre-set process variables with substantially least test runs needed which further helps in sustainability (Karmoker et al., 2019; Khuri and Cornell, 2018). The independent process variables investigated in this study were the unit cell (UC) size and strut diameter (SD) of the BCC topological lattice structure. Face central composite design (FCCD) experimental design was employed to keep the alpha, $\alpha= \pm 1$, this was done to satisfy the three levels of the unit cell size design parameter with a high of $30 \mathrm{~mm}$ and a low of $10 \mathrm{~mm}$ and with $\alpha= \pm 1$, the center point becomes $20 \mathrm{~mm}$. Otherwise, the unit cell size will be out of the $30 \mathrm{~mm}$ to $10 \mathrm{~mm}$ range. This is unfavorable because any size smaller than $10 \mathrm{~mm}$ is impractical. After all, it leads to high lattice density, which negates the benefits of a lightweight lattice structure. As such, unit cell sizes larger than $30 \mathrm{~mm}$ will not match the pre-set size of 60 $\mathrm{mm} 3$ and will need a larger size to accommodate the three levels of unit cell size, for instance, a $40 \mathrm{~mm}$ unit cell size with two levels of tessellation will result in 80 $\mathrm{mm} 3$ volume. The other design parameter is strut diameter with a high of $5 \mathrm{~mm}$ and a low of $3 \mathrm{~mm}$ and a center point of $4 \mathrm{~mm}$. Therefore, the region of interest for this study encompasses a range from $30 \mathrm{~mm}$ to 10 $\mathrm{mm}$ for unit cell size and $3 \mathrm{~mm}$ to $5 \mathrm{~mm}$ for strut diameter. With 1 replication for each factorial point and 5 replications for the center point, the total number of test experiments was 13 . The responses selected were the 1) modulus of elasticity which relates to stiffness,
2) yield stress which is important for load-bearing capability determination, and the derived of these two responses to give 3) specific stiffness and 4) specific strength for comparability to other studies by other researchers. These responses were analyzed using Minitab software version 19.1 with a $95 \%$ confidence level $(\mathrm{P}$-value $=0.05)$. Analysis of variance $($ ANOVA $)$ was used to assess the importance and contribution of each factor subjected to the analysis.

\subsection{Compression test}

Each lattice sample was compressed using an Instron 5585 universal compression test machine by adhering to ASTM D695-15 (standard test method for compressive properties of rigid plastics) as a guideline, all the data were recorded by using BlueHill 3 software. The samples were compressed at a quasi-static axial loading speed rate at $1.5 \mathrm{~mm} / \mathrm{min}$. To exclude the influence of the build printing orientation on the mechanical responses, all samples were loaded in the perpendicular upright direction with printing orientation (Bai et al., 2020; Hossain et al., 2021; Zeng et al., 2021). The samples were compressed just enough until yielding occurrence can be discerned graphically in stress-strain plots during the compression test. Fig. 2 shows the schematic of the compression setup. Several compression tests were done for some lattice samples to test for consistency and repeatability. It should be noted that the data inputted into the RSM table were not averaged data from these tests but data from an individual test each. However, as mentioned in the previous section, there were five replicates for the center point, these replicates should be enough to estimate pure error and give enough power for the 
lack of fit test where model fitness to data is tested (Pat, 2017). Replicated measurements for all factorial points will be inefficient as it is costly and time-consuming to collect.

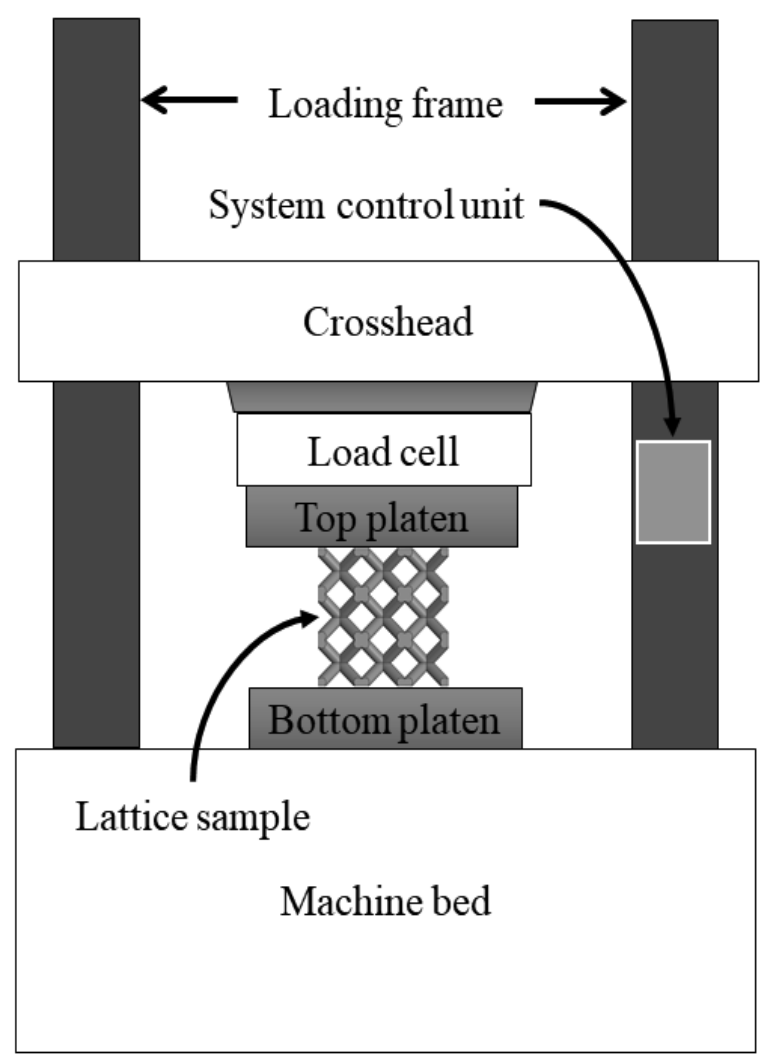

Fig. 2 Schematic diagram of the compression setup (not to scale)

\section{Results and discussion}

\subsection{The effect of the independent variable on mecha- nical responses}

Fig. 3 shows the stress-strain plots obtained from compression tests. The plots shown only up to maximum stress before plastic deformation occurs as all needed responses of interest can already be determined (Rashed et al., 2016; Syam et al., 2018). These plots are categorized according to the stress scale to give better readability. The slope of the linear part of the linear elastic region before yielding from the stressstrain plots gives the lattice moduli. Meanwhile, the yield stresses of the lattice structure were evaluated at the 0.2 percent elastic-plastic strain offset at which the built line intersected the existing stress-strain plot. In addition, the other next two responses were determined by dividing the above-mentioned responses namely young modulus and yield stress to the estimated lattice density. The estimated lattice density was calculated by dividing the measured mass of lattice samples to the solid volume of dimension $60 \mathrm{~mm} 3$ where the lattice structure is considered as not a solid block material (Hasan, 2013). It should be noted that the values of yield stresses tabulated in column five of Tab. 1 are lesser than what can graphically discern in Fig. 3. Hull and Bacon, (2011) mentioned that the yield stress is inexplicit where deformation due to dislocation is not a point of an occurrence but a continuous diffused progression, which means the yield stress could be anywhere along the yielding region. Besides that, Christensen, (2008) stated that the yield stresses computed from the $0.2 \%$ offset rule deviated from the actual yield stress at a point where nonlinearity can be graphically observed. However, due to difficulties in determining the yield stress resulted in the arbitrary method of adopting the $0.2 \%$ offset rule for convenience (Christensen, 2008). Therefore, the yield stresses values used in this study also adopting this method.

The responses measured for each sample from 13 sample test experiments were inputted into its respective columns and rows in Minitab software as tabulated in Tab. 1 in uncoded actual factors for easy readability. The 3D surface contour plots for each mechanical response are shown in Fig. 4. From the surface contour plots, it can be observed that the trend for all mechanical responses revealed an almost similar trend where the contour peaked at a combination of $10 \mathrm{~mm}$ and $5 \mathrm{~mm}$ unit cell size and strut diameter respectively. In contrast, a combination of $30 \mathrm{~mm}$ and 3 $\mathrm{mm}$ resulted in lowermost values. A similar trend can be observed in a study conducted by Monkova et al., (2021). Fig. 5 illustrates the mean effect plots for the unit cell size and strut diameter factors obtained through the Taguchi method. The mean effect plots of each response agree well with the contour plot where the unit cell size culminated at the lowest value while the strut diameter at the highest value and vice versa. Therefore, a combination of lowest and highest values for these two design parameters will be resulting in the extreme maximal and minimal values in the mechanical responses. From Fig. 5, it can be seen that the strut diameter has linear growth with mechanical responses which gives insight that either lowering or increasing the strut diameter will result in lower and higher mechanical responses. Similar response can be observed in study conducted by Hanzl et al., (2019). On the other hand, for unit cell size, further increases in unit cell size might have a slight effect on mechanical responses as it begins to plateau from $20 \mathrm{~mm}$ to 30 mm size. 

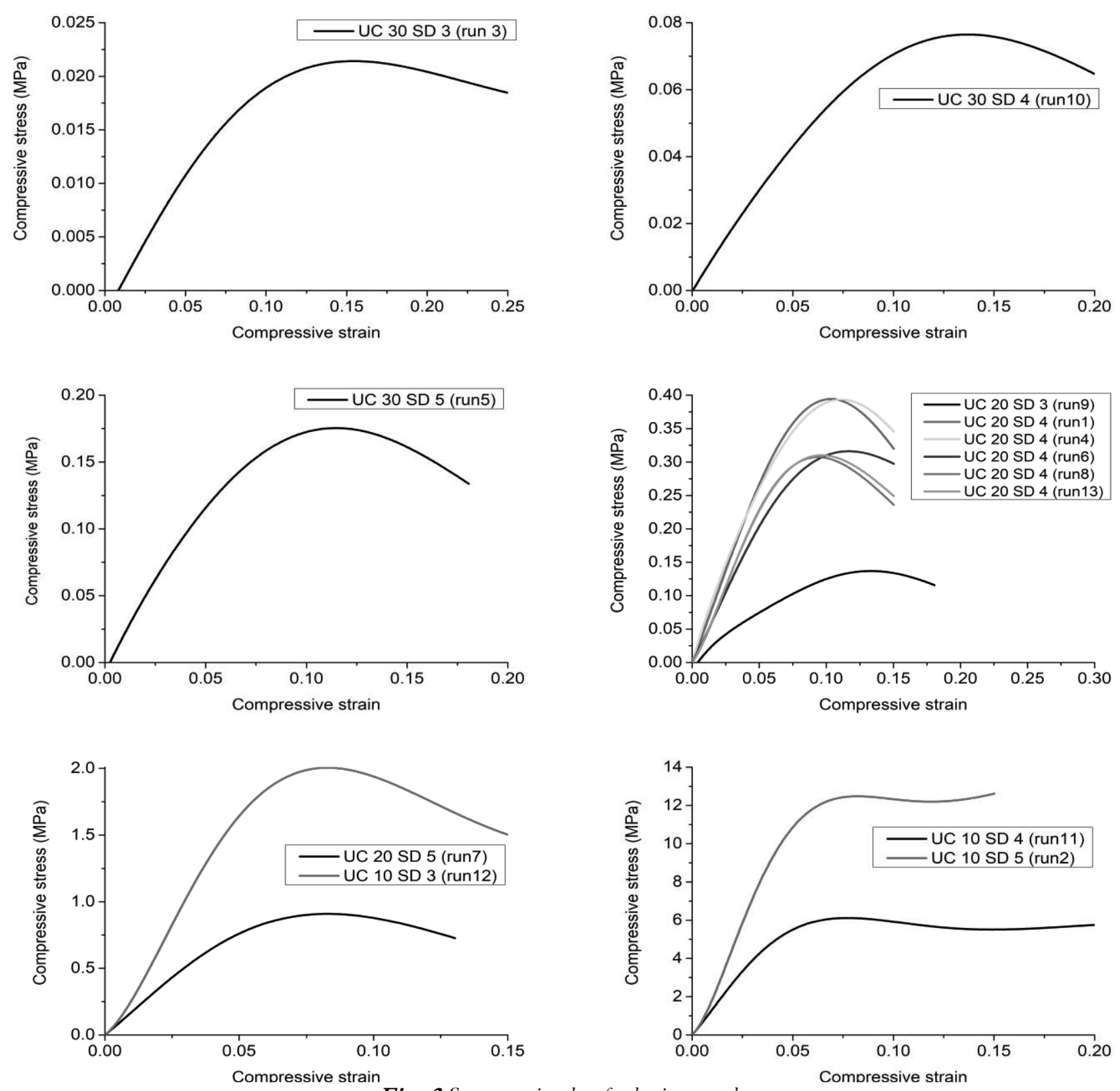

Fig. 3 Stress-strain plots for lattice samples

Tab. 1 Compression test results for lattice structure

\begin{tabular}{|c|c|c|c|c|c|c|}
\hline & \multicolumn{2}{|l|}{ Independent variable } & \multicolumn{4}{|c|}{ Mechanical response } \\
\hline $\begin{array}{l}\text { Run or- } \\
\text { der }\end{array}$ & $\begin{array}{l}\text { Strut diameter, SD } \\
(\mathrm{mm})\end{array}$ & $\begin{array}{l}\text { Unit cell, UC } \\
(\mathrm{mm})\end{array}$ & $\begin{array}{l}\text { Young modulus } \\
\text { (MPa) }\end{array}$ & $\begin{array}{l}\text { Yield } \\
\text { stress } \\
(\mathrm{MPa})\end{array}$ & $\begin{array}{l}\text { Specific stiff- } \\
\text { ness } \\
(1 \mathrm{e}-6 \mathrm{Nm} / \mathrm{g})\end{array}$ & $\begin{array}{l}\text { Specific } \\
\text { strength } \\
(1 \mathrm{e}-6 \mathrm{Nm} / \mathrm{g})\end{array}$ \\
\hline 1 & 4 & 20 & 6.08 & 0.24 & 37.52 & 1.49 \\
\hline 2 & 5 & 10 & 251.84 & 10.81 & 370.81 & 15.92 \\
\hline 3 & 3 & 30 & 0.24 & 0.02 & 5.36 & 0.34 \\
\hline 4 & 4 & 20 & 6.04 & 0.24 & 37.41 & 1.49 \\
\hline 5 & 5 & 30 & 2.08 & 0.15 & 17.81 & 1.27 \\
\hline 6 & 4 & 20 & 3.85 & 0.28 & 23.70 & 1.69 \\
\hline 7 & 5 & 20 & 16.61 & 0.74 & 69.39 & 3.10 \\
\hline 8 & 4 & 20 & 4.81 & 0.24 & 29.63 & 1.49 \\
\hline 9 & 3 & 20 & 1.56 & 0.08 & 16.23 & 0.84 \\
\hline 10 & 4 & 30 & 0.80 & 0.06 & 10.34 & 0.73 \\
\hline 11 & 4 & 10 & 132.85 & 5.30 & 262.53 & 10.47 \\
\hline 12 & 3 & 10 & 37.43 & 1.69 & 115.33 & 5.21 \\
\hline 13 & 4 & 20 & 4.89 & 0.23 & 30.25 & 1.44 \\
\hline
\end{tabular}




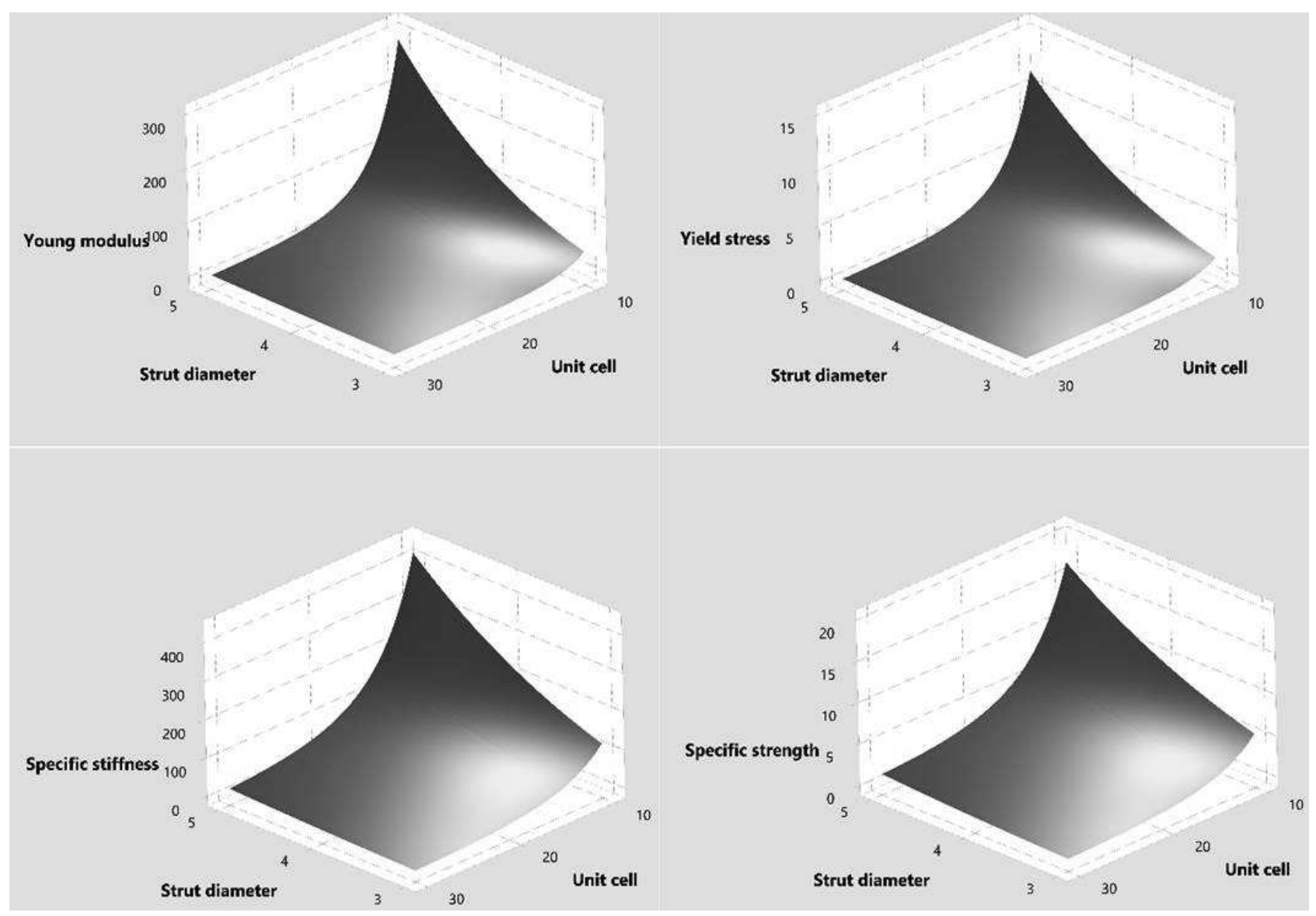

Fig. 4 Surface contour plots for mechanical responses with respect to strut diameter and unit cell size factors

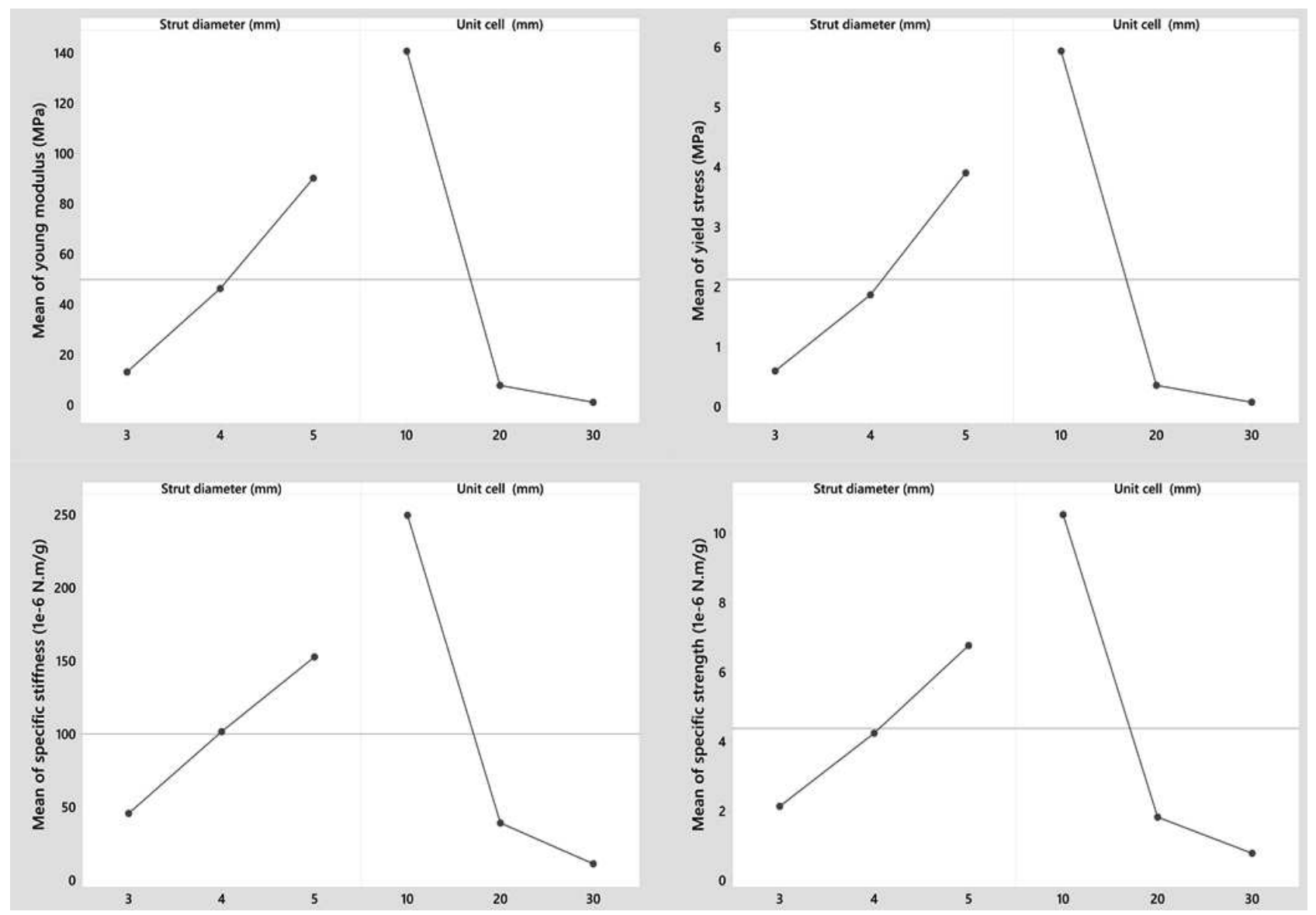

Fig. 5 Mean effect plots of mechanical responses for each input factor 


\subsection{Analysis of variance (ANOVA)}

Upon examination, due to the large ratio of maximum to minimum of each response range, Box-Cox transformation was required for each response. A diagnostic measure was employed to determine the appropriate type of transformation to obtain the optimal lambda value to produce the best transformation fitting. Hence, natural log transformation was used for each response as it represents growth data. Tab. 2, Tab. 3, Tab. 4, and Tab. 5 sum up the analysis of variance (ANOVA) for young modulus, yield stress, specific stiffness, and specific strength respectively.

Tab. 2 Analysis of variance for transformed response young modulus

\begin{tabular}{|c|c|c|c|c|c|c|c|c|c|}
\hline Source & $\begin{array}{l}\mathrm{D} \\
\mathrm{F}\end{array}$ & $\begin{array}{l}\text { Adj } \\
\text { SS }\end{array}$ & $\begin{array}{l}\text { Adj } \\
\text { MS }\end{array}$ & $\begin{array}{l}\text { F- } \\
\text { Value }\end{array}$ & $\begin{array}{l}\text { P- } \\
\text { Value }\end{array}$ & $\begin{array}{l}\text { Contribution } \\
\%\end{array}$ & R-sq & $\begin{array}{l}\text { R-sq } \\
\text { (pred) }\end{array}$ & $\mathrm{S}$ \\
\hline Strut diameter & 1 & 6.88 & 6.88 & 212.50 & 0.00 & 15.13 & & & \\
\hline Unit cell & 1 & 37.29 & 37.29 & $\begin{array}{l}1151.5 \\
1\end{array}$ & 0.00 & 82.01 & & & \\
\hline $\begin{array}{l}\text { Strut diameter } * \text { Strut di- } \\
\text { ameter }\end{array}$ & 1 & 0.03 & 0.03 & 0.89 & 0.38 & 0.06 & & & \\
\hline Unit cell $*$ Unit cell & 1 & 1.00 & 1.00 & 30.94 & 0.00 & 2.20 & & & \\
\hline Strut diameter $*$ Unit cell & 1 & 0.02 & 0.02 & 0.48 & 0.51 & 0.03 & & & \\
\hline Lack-of-Fit & 3 & 0.08 & 0.03 & 0.78 & 0.56 & 0.18 & & & \\
\hline Pure Error & 4 & 0.14 & 0.04 & & & 0.31 & & & \\
\hline Total & 12 & 45.46 & & & & & & & \\
\hline Model Summary & & & & & & & $\begin{array}{l}99.50 \\
\%\end{array}$ & $\begin{array}{l}97.92 \\
\%\end{array}$ & $\begin{array}{l}0.179 \\
9\end{array}$ \\
\hline
\end{tabular}

DF: degrees of freedom; Adj SS: adjusted sum of square; Adj MS: adjusted mean of square

Tab. 3 Analysis of variance for transformed response yield stress

\begin{tabular}{|c|c|c|c|c|c|c|c|c|c|}
\hline Source & $\begin{array}{l}\mathrm{D} \\
\mathrm{F}\end{array}$ & $\begin{array}{l}\text { Adj } \\
\text { SS }\end{array}$ & $\begin{array}{l}\text { Adj } \\
\text { MS }\end{array}$ & $\begin{array}{l}\text { F- } \\
\text { Value }\end{array}$ & $\begin{array}{l}\text { P- } \\
\text { Value }\end{array}$ & $\begin{array}{l}\text { Contribution } \\
\%\end{array}$ & R-sq & $\begin{array}{l}\text { R-sq } \\
\text { (pred) }\end{array}$ & S \\
\hline Strut diameter & 1 & 6.70 & 6.70 & 944.80 & 0.00 & 17.25 & & & \\
\hline Unit cell & 1 & 30.56 & 30.56 & $\begin{array}{l}4309.1 \\
9\end{array}$ & 0.00 & 78.70 & & & \\
\hline $\begin{array}{l}\text { Strut diameter } * \text { Strut di- } \\
\text { ameter }\end{array}$ & 1 & 0.02 & 0.02 & 3.29 & 0.11 & 0.06 & & & \\
\hline Unit cell $*$ Unit cell & 1 & 1.38 & 1.38 & 194.21 & 0.00 & 3.55 & & & \\
\hline Strut diameter $*$ Unit cell & 1 & 0.04 & 0.04 & 6.13 & 0.04 & 0.11 & & & \\
\hline Lack-of-Fit & 3 & 0.03 & 0.01 & 2.46 & 0.20 & 0.08 & & & \\
\hline Pure Error & 4 & 0.02 & 0.00 & & & 0.04 & & & \\
\hline Total & 12 & 38.83 & & & & & & & \\
\hline Model Summary & & & & & & & $\begin{array}{l}99.87 \\
\%\end{array}$ & $\begin{array}{l}99.30 \\
\%\end{array}$ & $\begin{array}{l}0.084 \\
2\end{array}$ \\
\hline
\end{tabular}

DF: degrees of freedom; Adj SS: adjusted sum of square; Adj MS: adjusted mean of square

Tab. 4 Analysis of variance for transformed response specific stiffness

\begin{tabular}{llllllllll}
\hline Source & D & $\begin{array}{l}\text { Adj } \\
\text { SS }\end{array}$ & $\begin{array}{l}\text { Adj } \\
\text { MS }\end{array}$ & $\begin{array}{l}\text { F- } \\
\text { Value }\end{array}$ & $\begin{array}{l}\text { P- } \\
\text { Value }\end{array}$ & $\begin{array}{l}\text { Contribution } \\
\%\end{array}$ & R-sq & $\begin{array}{l}\text { R-sq } \\
\text { (pred) }\end{array}$ & S \\
\hline Strut diameter & 1 & 2.43 & 2.43 & 79.45 & 0.00 & 13.76 & & \\
Unit cell & 1 & 14.54 & 14.54 & 474.50 & 0.00 & 82.19 & & \\
Strut diameter *Strut di- & 1 & 0.00 & 0.00 & 0.11 & 0.75 & 0.02 & & \\
ameter & 1 & 0.45 & 0.45 & 14.82 & 0.01 & 2.57 & & \\
Unit cell *Unit cell & 1 & 0.00 & 0.00 & 0.01 & 0.93 & 0.00 & & \\
Strut diameter *Unit cell & 1 & 3 & 0.07 & 0.02 & 0.62 & 0.64 & 0.39 & & \\
Lack-of-Fit & 4 & 0.15 & 0.04 & & & 0.83 & & & \\
Pure Error & 12 & 17.69 & & & & & & & \\
Total & & & & & & & 98.79 & 95.50 & 0.175 \\
Model Summary & & & & & & & $\%$ & $\%$ & 0 \\
\hline
\end{tabular}

DF: degrees of freedom; Adj SS: adjusted sum of square; Adj MS: adjusted mean of square 
Tab. 5 Analysis of variance for transformed response specific strength

\begin{tabular}{llllllllll}
\hline \multirow{2}{*}{ Source } & $\begin{array}{l}\text { D } \\
\text { F }\end{array}$ & $\begin{array}{l}\text { Adj } \\
\text { SS }\end{array}$ & $\begin{array}{l}\text { Adj } \\
\text { MS }\end{array}$ & $\begin{array}{l}\text { F- } \\
\text { Value }\end{array}$ & $\begin{array}{l}\text { P- } \\
\text { Value }\end{array}$ & $\begin{array}{l}\text { Contribution } \\
\%\end{array}$ & R-sq & $\begin{array}{l}\text { R-sq } \\
\text { (pred) }\end{array}$ & S \\
\hline Strut diameter & 1 & 2.33 & 2.33 & 388.46 & 0.00 & 17.05 & & \\
Unit cell & 1 & 10.46 & 10.46 & $\begin{array}{l}1746.3 \\
4\end{array}$ & 0.00 & 76.64 & & \\
$\begin{array}{l}\text { Strut diameter *Strut di- } \\
\text { ameter }\end{array}$ & 1 & 0.00 & 0.00 & 0.27 & 0.62 & 0.01 & & \\
Unit cell *Unit cell & 1 & 0.72 & 0.72 & 119.59 & 0.00 & 5.25 & & \\
Strut diameter *Unit cell & 1 & 0.01 & 0.01 & 1.68 & 0.24 & 0.07 & & \\
Lack-of-Fit & 3 & 0.03 & 0.01 & 2.09 & 0.24 & 0.19 & & \\
Pure Error & 4 & 0.02 & 0.00 & & & 0.12 & & \\
Total & 12 & 13.65 & & & & & & \\
Model Summary & & & & & & & 99.69 & 98.47 & 0.077 \\
\hline
\end{tabular}

DF: degrees of freedom; Adj SS: adjusted sum of square; Adj MS: adjusted mean of square

The statistical significance of individual factors and whether the interaction between them is important to individual response can be determined by the $\mathrm{p}$-value of less than 0.05 and a large $\mathrm{F}$-value. This means that there is a $5 \%$ risk of falsely assuming a model term has a significant effect where there is none. From Tab. 2, Tab. 4, and Tab. 5, it can be seen that the square term for strut diameter and the two-way interaction between strut diameter and unit cell size are not statistically significant. Meanwhile, from Tab. 3, only the square term of strut diameter is not significant. This gives insights that the interaction between unit cell size and strut diameter is only associated with yield stress but not with other mechanical responses. Apart from that, all other model terms are showing a great significance and are highly associated with young modulus, yield stress, specific stiffness as well as specific strength. For all cases, the unit cell size linear model term contributing the most for responses with at least $76.64 \%, 78.70 \%, 82.01 \%$, and up to $82.19 \%$ to the specific strength, yield stress, young modulus, and specific stiffness responses followed by the strut diameter linear model term accounted for $13.76 \%, 15.13 \%$, $17.05 \%$ and $17.25 \%$ for specific stiffness, young modulus, specific strength, and yield stress respectively. This is also observable from Fig. 5 where unit cell size gives inverse exponential growth as compared to almost linear growth for strut diameter. Other model terms have a low contribution to the responses. From the contribution percentage, it is apparent that the unit cell size model term has a higher influence on young modulus and its derivative, specific stiffness as compared to its influence to yield stress and its derivative, specific strength. On the contrary, the strut diameter model term has a higher influence to yield stress and its derivative than it is when compared to young modulus and its derivative, specific stiffness.

The goodness of fit of the model to data can be determined by referring to the S, R-sq, and predicted $\mathrm{R}$-sq. All models produced notably low $\mathrm{S}$ values which infer that the models can adequately describe the mechanical responses. High R-sq with the lowest of $98.79 \%$ indicates low variation in the responses. A similar high percent of predicted R-sq can be observed for all models with the lowest value of $95.50 \%$ give the apprehension that the models have excellent predictive ability. This is also shown by the not significant lack of fit term for all mechanical responses with a pvalue of more than 0.05 and small F-values implies the lack of fit is not significant relative to the pure error. Therefore, this indicates that the models fit well and can be used to accurately predict the corresponding response.

Fig. 6 shows the normal probability for residual plots and its corresponding residual vs fitted plots for all mechanical responses. From the normal probability plots, it can be seen no apparent departure from the approximate diagonal straight line can be observed which assured the data were normally distributed. Therefore, it can be concluded the combination of controlled factors presents a good fit with output responses which accurately depict the relationship between factors and responses (Kiernan, 2014). In addition, from the residual vs fitted plots, it can be seen that data were symmetrically and arbitrarily distributed with constant variance to the upper and lower half of the straight zero line. 
(a)
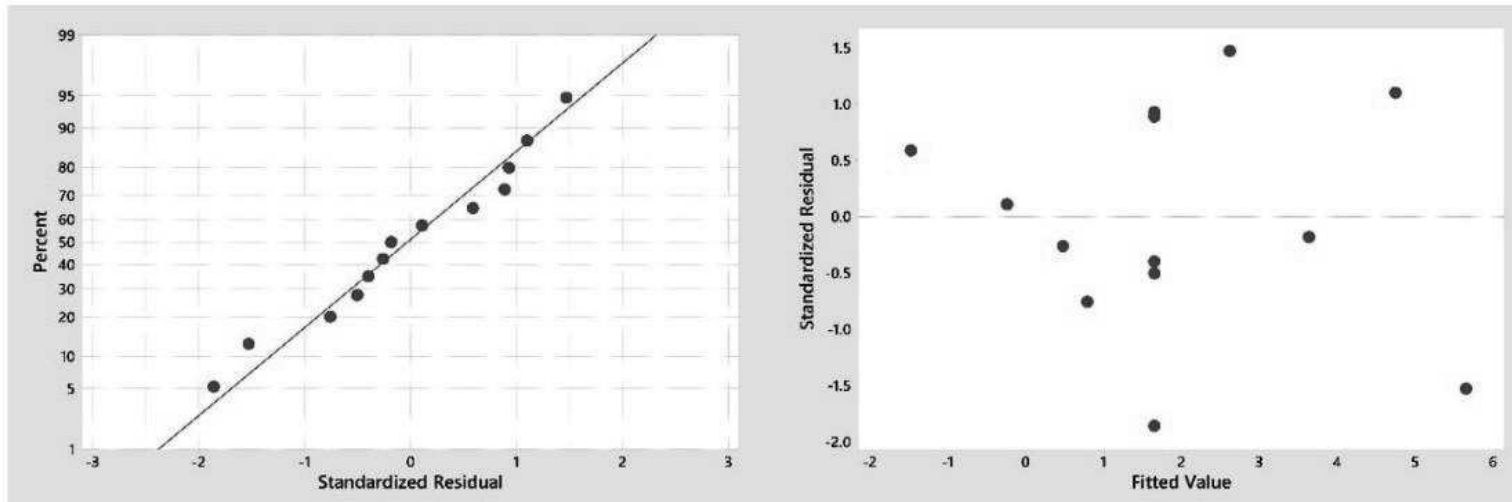

(b)
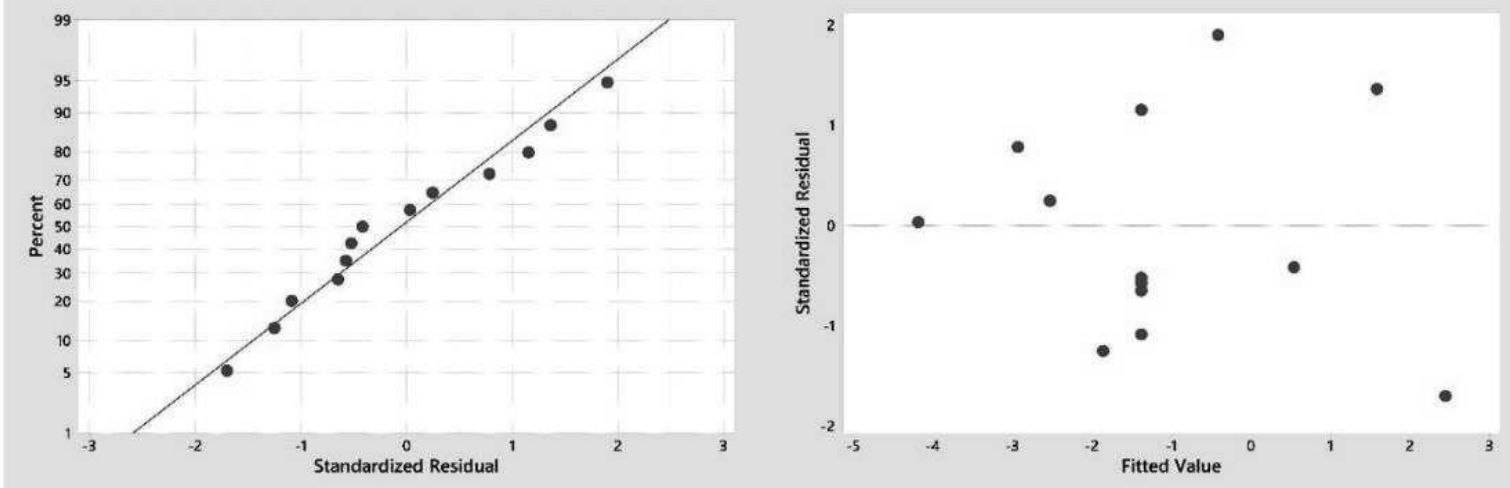

(c)
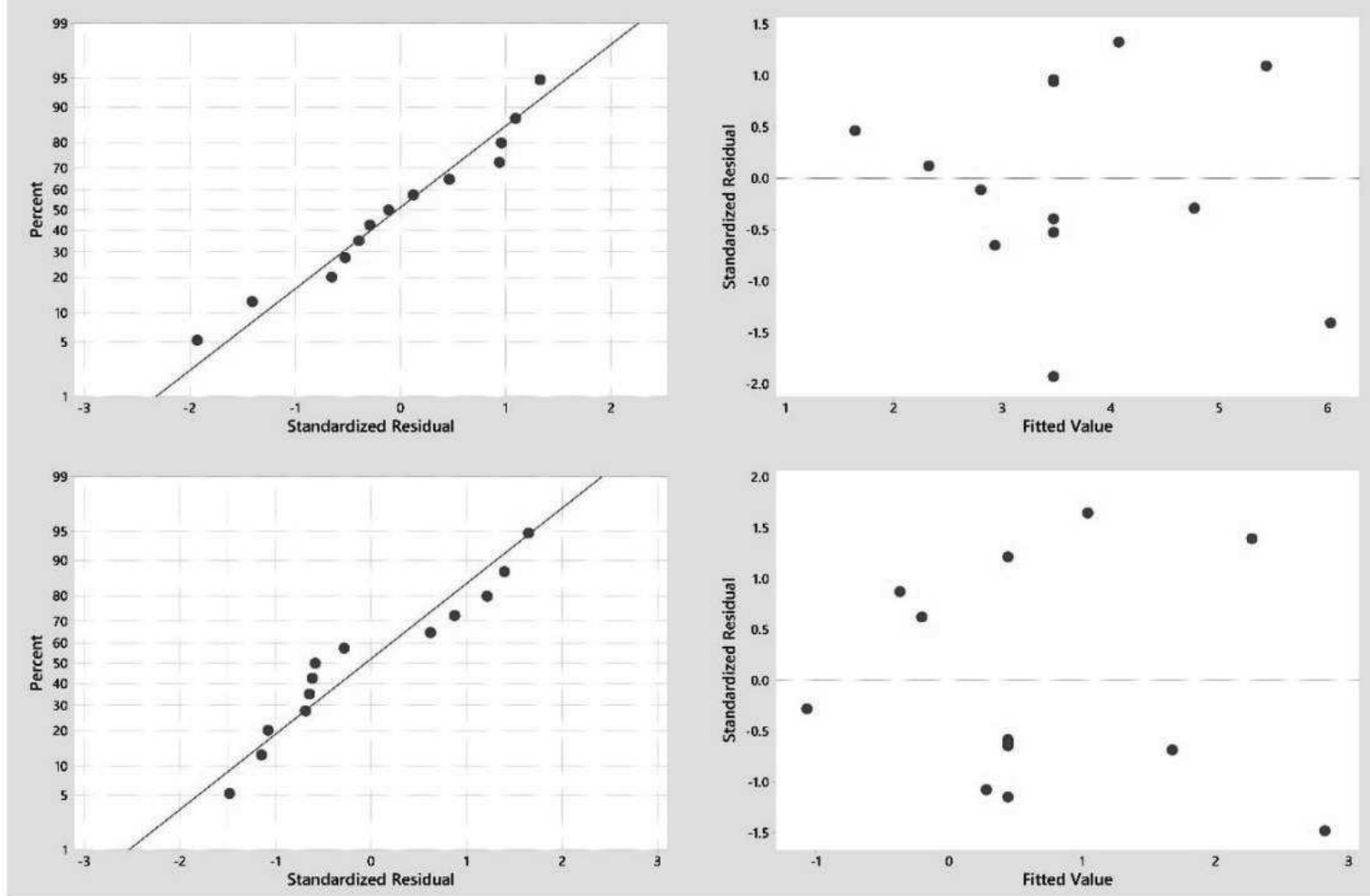

Fig. 6 Normal probability plot for residual and residual vs fitted values for (a) young modulus (b) yield stress (c) specific stiffness and (d) specific strength

The empirical relationship between mechanical response namely young modulus, yield stress, specific stiffness, and specific strength as a function of linear, square, and two-way interaction terms of the independent input factors strut diameter (SD) and unit cell size
(UC) are detailed in equations (1) to (4). The comparison between measured and predicted values using these equations is presented in Fig. 7. 
$\ln ($ young modulus $)=3.63+1.764 \mathrm{SD}-0.5151 \mathrm{UC}-0.102 \mathrm{SD}^{2}+0.00602 \mathrm{UC}^{2}+0.00623 \mathrm{SD} * \mathrm{UC}$

$\ln$ (yield stress) $=1.098+1.583 \mathrm{SD}-0.5498 \mathrm{UC}-0.0919 \mathrm{SD}^{2}+0.007061 \mathrm{UC}^{2}+0.01042 \mathrm{SD} * \mathrm{UC}$

$\ln$ (specific stiffness) $=5.17+0.897 \mathrm{SD}-0.3211 \mathrm{UC}-0.035 \mathrm{SD}^{2}+0.00405 \mathrm{UC}^{2}+0.00082 \mathrm{SD} * \mathrm{UC}$

$\ln$ (specific strength $)=2.643+0.716 \mathrm{SD}-0.3558 \mathrm{UC}-0.0242 \mathrm{SD}^{2}+0.005093 \mathrm{UC}^{2}+0.00502 \mathrm{SD} * \mathrm{UC}$
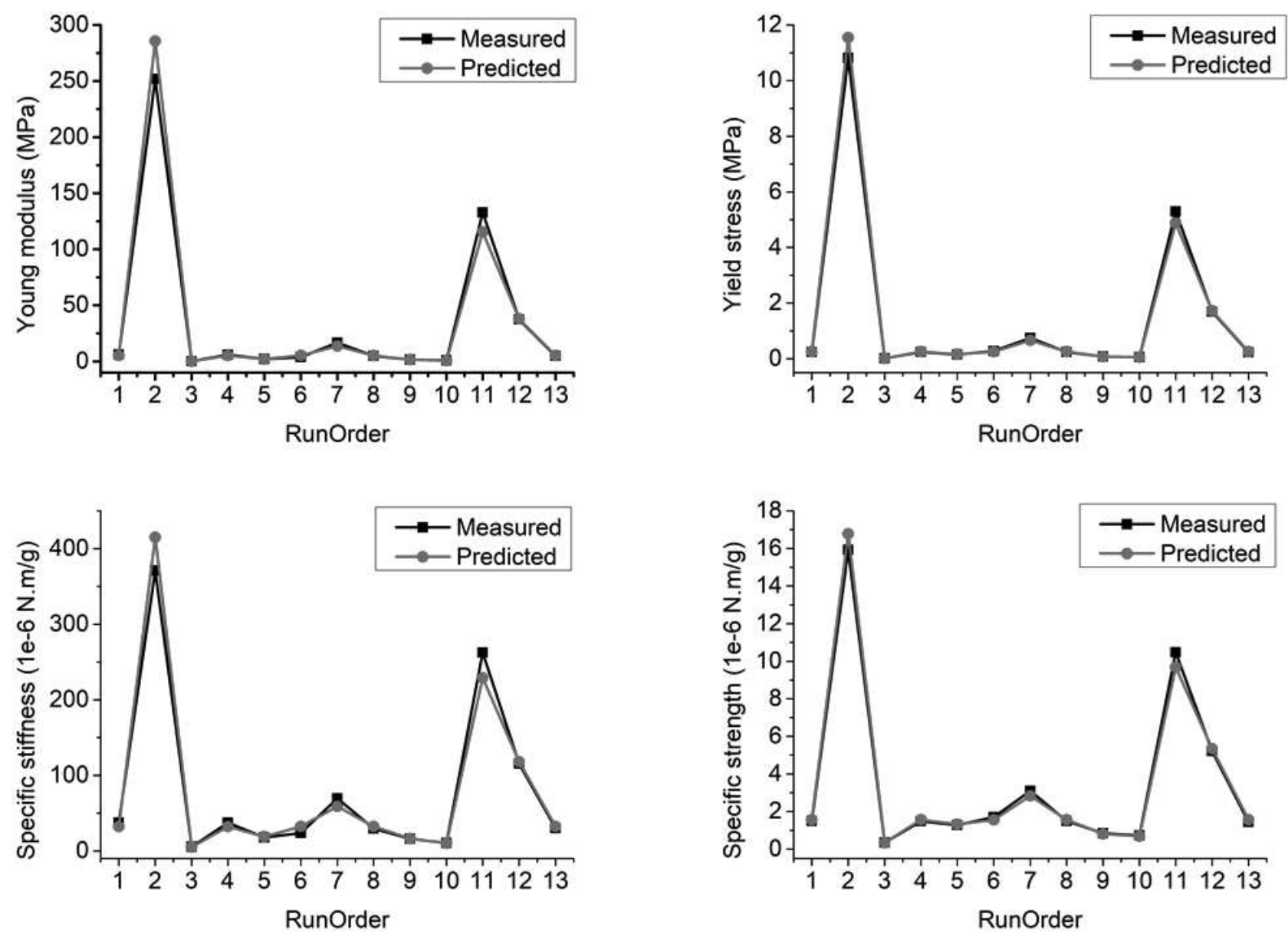

Fig. 7 Measured vs predicted comparison for mechanical responses

\subsection{Optimization of mechanical response for passive lattice vibration isolator}

The advantage of using RSM enables the responses to be optimized in accordance with pre-defined criteria by manipulating the input factors. A vibration isolator with low natural frequency is more favorable for a wider effective isolation region, this is achievable by using low stiffness material, as the stiffness is directly related to young modulus, hence low young modulus material. However, this diminishes the load-bearing capability culminating in excess deflection and result in overstressing of the material which proceeds to failure (Baravelli et al., 2013; Lagoudas et al., 2001; Yan and Gong, 2017; Zhang et al., 2019). The limit of load-bearing of a material is determined by its yield stress point. Typically, low young modulus material has a low yield stress limit where irreversible deformation occurred as the compressive behavior changes from elastic to plastic. However, there are instances where the structure can have low young modulus but high or comparable yield stress as illustrated in Fig. 8 which is the preferred case for passive vibration isolator as it provides a wider isolation region with better load-bearing capability (Matsumoto et al., 2005).

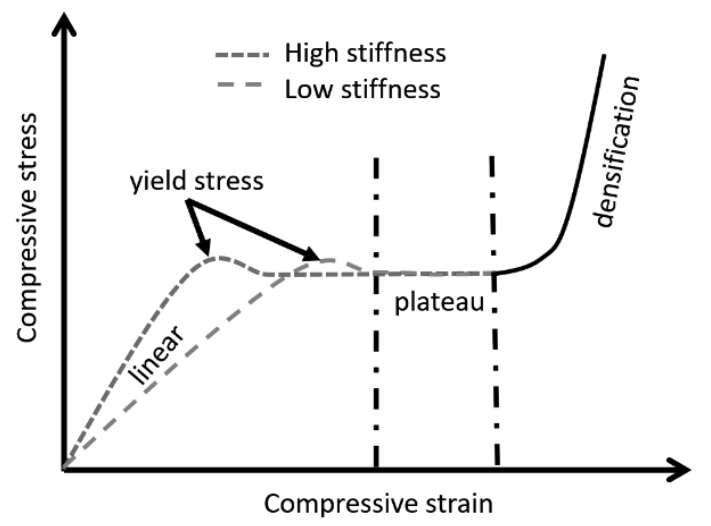

Fig. 8 Illustration of stress-strain plots for low stiffness and high stiffness material

Minitab response optimizer was used to find the optimum combination of input factors. The upper, 
lower, and target responses according to selected response goals to meet the aforementioned criteria above are tabulated in Tab. 6. The optimum condition for the output responses is displayed in Fig. 9 with composite desirability of 0.49 . There were four solutions suggested by the response optimizer following pre-selected goals, the first and fourth solutions were used for the confirmation test, the results from the confirmation test are tabulated in Tab. 7, the strut diameter used for solution 1 was rounded to $3.9 \mathrm{~mm}$ due to limitation of the machine used. The confirmation test revealed a good agreement between predicted and measured values with percentage errors of a maximum of $10.03 \%$.

Tab. 6 Lower, target, and upper value of responses for low stiffness and high yield stress lattice structure

\begin{tabular}{llccc}
\hline Response & Goal & Lower & Target & Upper \\
\hline Young modulus (MPa) & Minimum & & 0.2 & 251.8 \\
Yield stress (MPa) & Maximum & 0.0 & 10.8 & \\
Specific stiffness (1e-6 N.m/g) & Minimum & & 5.4 & 370.8 \\
Specific strength (1e-6 N.m/g) & Maximum & 0.3 & 15.9 & \\
\hline
\end{tabular}

Tab. 7 Confirmation test at response optimizer solution 1 and solution 4

\begin{tabular}{lllllll}
\hline Solution & $1(\mathrm{SD}=3.9 \mathrm{UC}=10)$ & \multicolumn{4}{l}{ 4 $(\mathrm{SD}=5 \mathrm{UC}=30)$} \\
\hline \multirow{2}{*}{ Responses } & $\begin{array}{l}\text { Measured } \\
\text { value }\end{array}$ & $\begin{array}{l}\text { Predicted } \\
\text { value }\end{array}$ & $\begin{array}{l}\text { Percentage } \\
\text { error }(\%)\end{array}$ & $\begin{array}{l}\text { Measured } \\
\text { value }\end{array}$ & $\begin{array}{l}\text { Predicted } \\
\text { value }\end{array}$ & $\begin{array}{l}\text { Percentage } \\
\text { error }(\%)\end{array}$ \\
\hline Young modulus & 103.0 & 92.7 & 10.0 & 2.2 & 2.1 & 6.0 \\
Yield stress & 4.4 & 4.0 & 9.8 & 0.2 & 0.2 & 3.4 \\
Specific stiffness & 213.6 & 209.3 & 2.0 & 18.8 & 17.8 & 5.1 \\
Specific strength & 9.1 & 8.9 & 1.8 & 1.3 & 1.4 & 4.4 \\
\hline
\end{tabular}

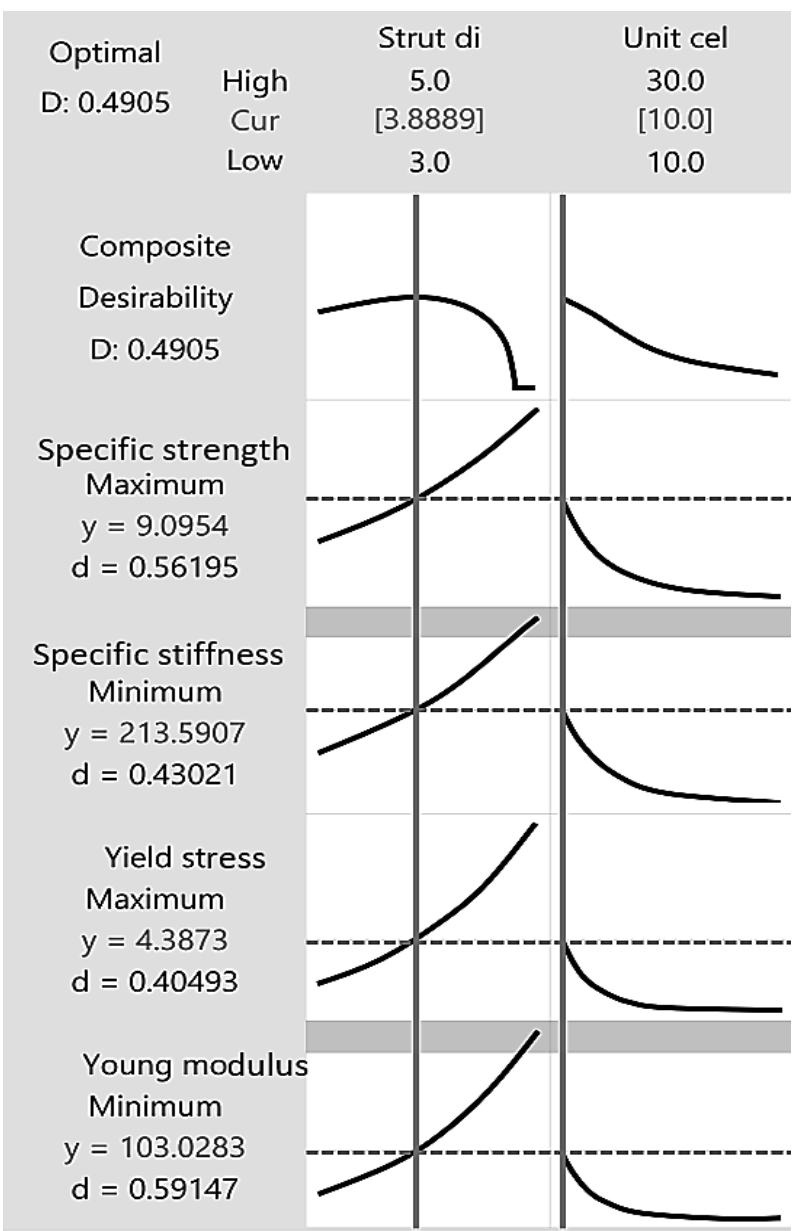

Fig. 9 The optimal condition for low stiffness and high yield stress lattice structure

\section{Conclusions}

In this study, the influence of unit cell size and strut diameter design parameters of BCC lattice structure made via FDM additive manufacturing on mechanical responses was investigated statistically using RSM DoE. Through RSM, the statistical importance of each input factor and its influence on each mechanical response is understood and subsequently, the empirical relationship between input factors and each mechanical response was formulated into individual equations for each response. Using these equations, the confirmation test shown good agreement with measured values with acceptable percentage errors. It can be concluded the unit cell size linear term contributes the most to the responses followed by the strut diameter linear term. Decreasing or increasing the strut diameter will result in lower and higher mechanical responses. On the other hand, for unit cell size, a further increase in unit cell size than $30 \mathrm{~mm}$ might have a slight effect on mechanical responses. Thru optimization, the predicted combination of strut diameter $3.9 \mathrm{~mm}$ and unit cell size of $10 \mathrm{~mm}$ provides the best result for low stiffness and high yield stress criteria. However, the result only produced $0.49 \%$ composite desirability. Findings give insight that to vastly tune the lattice structure, unit cell size design parameter is the advantageous route while strut diameter is for finetuning the lattice structure. The recommendations for future works are to include other design parameters of the lattice structure that can give better composite de- 
sirability to better satisfies the goal for passive vibration isolation application. Other work can also include a case study that attests to the potential of lattice structure to real passive vibration isolation application.

\section{Acknowledgement}

The authors acknowledge the scholarship from Zamalah Scheme, Universiti Teknikal Malaysia Melaka.

\section{References}

[1] ABDULHADI, H.S. AND MIAN, A. (2019), "Effect of strut length and orientation on elastic mechanical response of modified bodycentered cubic lattice structures", Proceedings of the Institution of Mechanical Engineers, Part L: Journal of Materials: Design and Applications, Vol. 233 No. 11, pp. 2219-2233.

[2] ASHBY, M.F., EVANS, T., FLECK, N.A., HUTCHINSON, J.W., WADLEY, H.N.G. AND GIBSON, L.J. (2000), Metal Foams: $A$ Design Guide, Elsevier.

[3] BAI, L., ZHANG, J., XIONG, Y., CHEN, X., SUN, Y., GONG, C., PU, H., ET AL. (2020), "Influence of unit cell pose on the mechanical properties of Ti6Al4V lattice structures manufactured by selective laser melting", Additive Manufacturing, Vol. 34, p. 101222.

[4] BARAVELLI, E., CARRARA, M. AND RUZZENE, M. (2013), "High stiffness, high damping chiral metamaterial assemblies for low-frequency applications", Health Monitoring of Structural and Biological Systems 2013, Vol. 8695, p. $86952 \mathrm{~K}$.

[5] BUONAMICI, F., CARFAGNI, M., FURFERI, R., GOVERNI, L., SACCARDI, M. AND VOLPE, Y. (2018), "Optimizing fabrication outcome in low-cost FDM machines. Part 2 - Tests", Manufacturing Technology, Vol. 18 No. 4, pp. 552-558.

[6] CHRISTENSEN, R.M. (2008), "Observations on the definition of yield stress", Acta Mechanica, Vol. 196 No. 3, pp. 239-244.

[7] DENG, Y., MAO, Z., YANG, N., NIU, X. AND LU, X. (2020), "Collaborative optimization of density and surface roughness of 316L stainless steel in selective laser melting", Materials, Vol. 13 No. 7, p. 1601.

[8] EL-SAYED, M.A., ESSA, K., GHAZY, M. AND HASSANIN, H. (2020), "Design optimization of additively manufactured titanium lattice structures for biomedical implants", The International Journal of Advanced
Manufacturing Technology, Vol. 110 No. 9, pp. 2257-2268.

[9] ELMADIH, W.A., SYAM, W.P., MASKERY, I. AND LEACH, R. (2017), "Additively manufactured lattice structures for precision engineering applications", In Proceedings of the 32nd Annual Meeting of American Society for Precision Engineering, pp. 164-169.

[10] GAUTAM, R. AND IDAPALAPATI, S. (2019), "Compressive properties of additively manufactured functionally graded Kagome lattice structure", Metals, Vol. 9 No. 5, p. 517.

[11] HANZL, P., ZETKOVÁ, I. AND CAJTHAMLOVÁ, Š. (2019). "Influence of strut diameter and building direction on strength of lattice structure", Manufacturing Technology, Vol. 19 No. 6, pp. 947-951.

[12] HASAN, R. (2013), Progressive Collapse of Titanium Alloy Micro-Lattice Structures Manufactured Using Selective Laser Melting, University of Liverpool.

[13] HELOU, M. AND KARA, S. (2018), "Design, analysis and manufacturing of lattice structures: an overview", International Journal of Computer Integrated Manufacturing, Vol. 31 No. 3, pp. 243261.

[14] HOSSAIN, U., GHOUSE, S., NAI, K. AND JEFFERS, J.R. (2021), "Controlling and testing anisotropy in additively manufactured stochastic structures", Additive Manufacturing, Vol. 39, p. 101849.

[15] HULL, D. AND BACON, D.J. (2011), Introduction to Dislocations, Elsevier.

[16] IYIBILGIN, O., YIGIT, C. AND LEU, M.C. (2013), "Experimental investigation of different cellular lattice structures manufactured by fused deposition modeling", Proceedings of the Solid Freeform Fabrication Symposium, Austin, TX, USA, pp. 895-907.

[17] KARMOKER, J.R., HASAN, I., AHMED, N., SAIFUDDIN, M. AND REZA, M.S. (2019), "Development and Optimization of Acyclovir Loaded Mucoadhesive Microspheres by BoxBehnken Design", Dhaka University Journal of Pharmacentical Sciences, Vol. 18 No. 1, pp. 1-12.

[18] KHURI, A.I. (2001), “An overview of the use of generalized linear models in response surface methodology", Nonlinear Analysis: Theory, Methods \& Applications, Vol. 47 No. 3, pp. 2023 2034.

[19] KHURI, A.I. AND CORNELL, J.A. (2018), Response Surfaces: Designs and Analyses, Routledge. 
[20] KIERNAN, D. (2014), Natural Resources Biometrics, Open SUNY Textbooks.

[21] LAGOUDAS, D.C., MAYES, J.J. AND KHAN, M.M. (2001), "Simplified shape memory alloy (SMA) material model for vibration isolation", Smart Structures and Materials 2001: Modeling, Signal Processing, and Control in Smart Structures, Vol. 4326, pp. 452461.

[22] MAHSHID, R., HANSEN, H.N. AND HØJBJERRE, K.L. (2016), "Strength analysis and modeling of cellular lattice structures manufactured using selective laser melting for tooling applications", Materials \& Design, Vol. 104, pp. 276-283.

[23] MASKERY, I., HUSSEY, A., PANESAR, A., AREMU, A., TUCK, C., ASHCROFT, I. AND HAGUE, R. (2017), "An investigation into reinforced and functionally graded lattice structures", Journal of Cellular Plastics, Vol. 53 No. 2, pp. 151-165.

[24] MATSUMOTO, H., WATANABE, S. AND HANADA, S. (2005), "Beta TiNbSn alloys with low Young's modulus and high strength", Materials Transactions, Vol. 46 No. 5, pp. 1070 1078.

[25] MONKOVA, K., VASINA, M., ZALUDEK, M., MONKA, P.P. AND TKAC, J. (2021), "Mechanical Vibration Damping and Compression Properties of a Lattice Structure", Materials, Vol. 14 No. 6, p. 1502.

[26] NGO, T.D., KASHANI, A., IMBALZANO, G., NGUYEN, K.T.Q. AND HUI, D. (2018), "Additive manufacturing (3D printing): A review of materials, methods, applications and challenges", Composites Part B: Engineering, Vol. 143, pp. 172-196.

[27] PAT. (2017), "The importance of center points in central composite designs", available at: https://www.statease.com/blog/importancecenter-points-central-composite-designs / (accessed 15 August 2021).

[28] PERniCA, J., SUSTR, M., DOstal, P., BRABEC, M. AND DOBROCKY, D. (2021), "Tensile Testing of 3D Printed Materials Made by Different Temperature", Manufacturing Technology, Vol. 21 No. 3, pp. 398-404.

[29] RASHED, M.G., ASHRAF, M., MINES, R.A.W. AND HAZELL, P.J. (2016), "Metallic microlattice materials: A current state of the art on manufacturing, mechanical properties and applications", Materials \& Design, Vol. 95, pp. 518-533.
[30] ROSLI, N.A., HASAN, R., ALKAHARI, M.R. AND TOKOROYAMA, T. (2017), "Effect of process parameters on the geometrical quality of ABS polymer lattice structure", Proceedings of SAKURA Symposium on Mechanical Science and Engineering 2017, pp. 3-5.

[31] SYAM, W.P., JIANWEI, W., ZHAO, B., MASKERY, I., ELMADIH, W. AND LEACH, R. (2018), "Design and analysis of strut-based lattice structures for vibration isolation", Precision Engineering, Vol. 52, pp. 494506.

[32] TERNER, M., RICORDEL, T., CHO, J.-H. AND LEE, J.-S. (2019), "The response surface methodology for optimizing the process parameters of selective laser melting", Journal of Welding and Joining, Vol. 37 No. 1, pp. 27-39.

[33] VILANOVA, M., ESCRIBANO-GARCÍA, R., GURAYA, T. AND SAN SEBASTIAN, M. (2020), "Optimizing Laser Powder Bed Fusion Parameters for IN-738LC by Response Surface Method", Materials, Vol. 13 No. 21, p. 4879.

[34] WANG, G., HUANG, L., LIU, Z., QIN, Z., HE, W., LIU, F., CHEN, C., ET AL. (2020), "Process optimization and mechanical properties of oxide dispersion strengthened nickel-based superalloy by selective laser melting", Materials \& Design, Vol. 188, p. 108418.

[35] YAN, L. AND GONG, X. (2017), "Experimental study of vibration isolation characteristics of a geometric anti-spring isolator", Applied Sciences, Vol. 7 No. 7, p. 711.

[36] ZENG, C., LIU, L., BIAN, W., LENG, J. AND LIU, Y. (2021), "Compression behavior and energy absorption of 3D printed continuous fiber reinforced composite honeycomb structures with shape memory effects", Additive Manufacturing, Vol. 38, p. 101842.

[37] ZHANG, F., SHAO, S., TIAN, Z., XU, M. AND XIE, S. (2019), "Active-passive hybrid vibration isolation with magnetic negative stiffness isolator based on Maxwell normal stress", Mechanical Systems and Signal Processing, Vol. 123, pp. 244-263.

[38] ZHANG, L., FEIH, S., DAYNES, S., CHANG, S., WANG, M.Y., WEI, J. AND LU, W.F. (2018), "Energy absorption characteristics of metallic triply periodic minimal surface sheet structures under compressive loading", Additive Manufacturing, Vol. 23, pp. 505-515. 